\title{
On the Path of Promoting College students' Key Competences in the New era-from the perspective of ideological and political Education
}

\author{
Lu Yuan Xia
}

Guangdong mechanical \& electrical Vocational and Technical College, Guangzhou, Guangdong, China

Keywords: Key competence; College students; Education; New era

\begin{abstract}
It is of great significance to cultivate moral character and cultivate people and improve the Key Competences of college students. From the perspective of ideological and political education, to effectively improve college students' Key Competences, it is necessary to clarify the connotation of the era of "Key Competences", understand the internal relationship between ideological and political education and improving Key Competences, and explore feasible and effective new paths based on a new perspective.
\end{abstract}

\section{新时代提升大学生核心素养的路径探析 基于思想政治教育的视角}

\author{
卢苑霞 \\ 广东机电职业技术学院，广州，广东，中国
}

关键词：核心素养; 大学生; 教育; 新时代

中文摘要：立德树人，提升大学生核心素养，有着重要意义。在思想政治教育视角下，有效 提升大学生核心素养, 需厘清 “核心素养” 的时代内涵, 认识思想政治教育与提升核心素养 的内在联系, 基于全新的视角, 探寻可行有效的新路径。

\section{1. 引言}

核心素养的研究是一种国际共识。时代发展的变化呼唤核心素养的出现。习总书记多次 强调, 要落实立德树人根本任务。教育部颁发的《关于全面深化课程改革, 落实立德树人根 本任务的意见》，将“核心素养”置于落实立德树人任务的基础地位。新时代，提升大学生核 心素养，已成为高校提高人才培养质量的关键环节。

\section{2. 提升大学生核心素养的新时代内涵}

近几年，核心素养成为教育领域的热点词汇。“所谓“学生发展核心素养”，是指学生应具 备的, 能够适应终身发展和社会发展需要的必备品格和关键能力”[1]。素养“不只重视知识, 也重视能力, 更强调态度”[2]。那些最关键、最基本、最必需, 在素养构成中居于核心地位的 素养就是核心素养 (Key Competences)。

厘清核心素养的内涵，需充分认识核心素养与相关概念的区别。相对于一般素养而言， 核心素养是少而精的。核心素养不等同于“综合素养”, 不可能面面俱到。它是关键的素养, 是比较基础比较主要的部分, 而不是包含所有的素养。核心素养也不等同于“核心能力”。是“必 备品格和关键能力”, 也就是说，核心素养内在地包含“核心能力”，但又不止于“核心能力”, 
还包括“必备品格”部分。

再结合核心素养应包含的基本内容，或许更容易理解核心素养的新时代内涵。“必备品格” 应包括家国情怀、责任担当、科学精神，人文关怀等等。“关键能力”应包括健康生活能力、 创新能力、学习能力、适应能力、运用科技的能力等等。

新时代提升大学生核心素养应聚焦的基本内容如下:

1、厚植家国情怀，引导学生践行社会主义核心价值观。2、更加注重健康生活教育，提 升健康生活能力。3、提升自主学习能力和知识运用能力。4、培养创新思维。5、增强适应能 力。包括与不同的人愉快相处, 适应不同的文化等。在“一带一路”战略背景下, 还应具有全 球意识和人类命运共同体意识等。

\section{3. 提升核心素养与思想政治教育的内在联系}

\section{1 两者的根本目的是一致的}

都是为了立德树人，培养能够适应社会发展和终身发展需要的人才，为建设有中国特色 的社会主义，实现共产主义而努力奋斗。只是“思想政治教育”的内容更倾向于思想、政治、 道德方面。“核心素养”更倾向于“关键”品格和能力。

\section{2 两者相辅相成, 互相促进}

习总的多次讲话，凸显了新时期大学生思想政治教育的重要性。提升大学生核心素养是 高校思想政治教育的重要内容之一。在提升大学生核心素养的过程中，思想政治教育处于非 常重要的地位。高校思想政治教育工作开展得好, 无疑也有利于大学生核心素养的提升。思 想政治教育有利于提升学生的思想政治素质和道德素质, 增强学生的家国情怀、社会责任感, 提升政治素养和道德修养，从而从根本上有利于提升学生的核心素养。提升核心素养，在促 进大学生立德成才等方面具有很强的导向作用，有利于学生的全面发展。思想政治素养是大 学生核心素养体系的构成要素之一, 是核心素养体系中的灵魂, 起着导向作用。因此, 在当 前的国际国内背景下，应发展基于核心素养的思想政治教育模式。

\section{4.新时代提升大学生核心素养应具有的新视角}

\section{1 充分尊重教育对象的主体性，激发内生动力}

只有充分了解教育对象，并充分尊重教育对象的主体性，才能取得较好教育效果。培养 大学生核心素养, 须把握主体维度, 充分了解新时代大学生。当前很多的教育往往从社会方 面去理解, 而没有从个体方面去理解, 没有关注大学生的思想特点, 忽略了大学生的个性化 特征和需求，导致教育效果不太理想。

当前大学生喜欢接触新生事物, 注重生活品质, 学习方式和生活方式都发生了很大变化, 思想观念、价值观多元化。这启示我们，在育人过程中，应当用发展变化的眼光看待当代大 学生, 充分尊重他们的主体性, 而不是一味思考怎么施加教育, 应当让他们主动学习、主动 成长。激发他们提升核心素养的内驱力, 点燃他们学习成长的核动力, 才能外化为行动。充 分把握主体维度, 才能了解提升大学生核心素养的内生动力和外生动力所在, 从而更有针对 性地做好育人工作。

\section{2 充分认清时代的新变化，铸魂育人}

当前中国的发展面临良好的机遇和挑战。要提升当代大学生核心素养，需结合时代背景， 结合党和国家发展境遇与发展战略，结合伟大复兴的中国梦的实现，结合我国“一带一路”战 
略, 用习近平新时代中国特色社会主义思想铸魂育人。应注重家国情怀、科技创新、文化自 信等教育。培养工匠精神、国际交流与合作的能力，培养新时代复合型人才。

时代变化了，对人才的要求也会发生对应的变化。大数据和人工智能时代，知识的更新 周期缩短, 人们需要不断学习新知识才能跟上时代的步伐。高校应充分立足时代的新变化, 以更高标准做好新时代育人工作。

\section{3 充分运用最新的教育载体和技术}

时代在改变着教育模式。当前, 教育技术呈现网络化、多媒体化等特点、人工智能在教 育中的应用愈来愈广泛, 教育技术应用模式呈现多元化特征。高校育人工作要有时代感和吸 引力。新时代教育如果载体单一, 缺乏创新, 势必会缺乏吸引力。创新教载体, 方能适应基 于互联网、信息化高速发展下的教育变革，实现教育内涵式发展。应充分运用微信等新兴载 体进行知识传播, 通过深受青年大学生喜欢的微电影、动漫、抖音等形式加强教育, 并通过 微信朋友圈等广泛宣传, 让时尚新元素成为教育新载体, 增强教育吸引力。

\section{5.基于思想政治教育视角的提升大学生核心素养的新路径}

思想政治教育下的核心素养提升，有着重要意义。高校可通过以下路径，促进大学生核 心素养的提升:

\section{1 加强顶层设计，构筑新型教学关系}

提升大学生核心素养, 高校需加强顶层设计。发挥课堂主渠道作用, 安排师德一流、素 质能力一流的教师队伍上好思想政治理论课、军事理论课等。同时开发新课程, 如《当代社 会生存能力》、《创新思维训练》、《人际沟通能力》、《跨文化交流》等课程。构筑与时 俱进的课程体系。

新时代提升大学生核心素养，还应把握思想政治教育的规律，构建以学生为本的新型教 学关系。打造一流师资, 促使学生自主学习、主动发展, 着力提升核心素养。以学生发展为 本, 提升教育教学质量, 倡导学生主动参与, 乐于探究。教师在教学过程中, 应当与学生积 极互动、主动交流, 实现教学相长。教师要善于结合现代教育技术和手段, 掌握教育艺术, 加强思想政治教育, 真正成为学生学习的帮助者和引导者, 使学生们能得到充分的发展。

\section{2 形成科学的核心素养评价机制}

高校在提升大学生核心素养过程中可采用积分制形式，与学生的日常思想政治教育和日 常管理相结合，结合第二课堂成绩单，把政治素养、道德修养、创新创业、文艺体育、劳动 实践等表现纳入考核。不良行为扣分为主, 优秀行为加分为主, 将每位学生的核心素养分数 与的毕业学分挂钩。可制定《学生核心素养评分细则》和相关规定, 根据学生的政治素养、 操行素养、创新创业、自主学习、素质拓展、社会实践等的表现，。以此调动学生参与各类 学习和活动、提升核心素养的积极性。各高校可根据实际在实践中进一步完善考评机制, 可 结合现代教育技术, 建立APP等平台, 认证学生的核心素养学分。通过各种先进技术和手段, 不断完善管理评价机制。

\section{3 开展特色实践育人和服务育人活动}

高校应高度重视实践育人，开展特色实践活动，利用暑期“三下乡”等活动，动员广大学 生到基层体验国情民生, 感受红色文化的熏陶, 涵养家国情怀。引导学生在实践中学习贯彻“习 近平新时代中国特色社会主义思想”, 践行社会主义核心价值观。也可通过生动活泼的形式开 展义修、科普、义教，送科技下乡、关爱留守儿童等活动。并做好活动的指导及经费的支持 等相关工作。平时多举行各类与核心素养相关的竞赛活动, 并增强竞赛活动的吸引力和感召 
力。平时引导学生积极参与“立志. 修身. 博学. 报国”等活动, 搭建志愿服务平台, 结合学 生的专业特长开展志愿服务活动, 引导大学生们在奉献中锤炼品格和能力。

高校还应立足专业，充分利用资源，完善校企联合协同育人机制，搭建各类平台，为大 学生提供更多的实习实践机会。如加强与校外实践基地的合作，创造条件加强国际交流与实 践等。在“一带一路”战略下，可以加强与一带一路沿线国家的高校和企业合作，开展各类创 新创业实践、社会服务活动和调研活动。引导学生在服务中感受不同文化, 并传播我国优秀 文化。这有利于培养大学生的国际化生存能力, 也有利于增强他们的爱国情怀和人类命运共 同体意识。

\section{4 实施榜样引领工程, 激发大学生成长成才动力}

新时代大学生喜欢关注朋辈的爱好、价值观与动态, 喜欢被朋辈关注。较之以教师主导, 朋辈间的心理距离更为接近。因此, 引导大学生向同辈先进榜样学习, 有意想不到的效果。 高校可充分运用更贴近“90后”、“00后”大学生的各种激励方式，实施榜样引领工程，在校内 公共场合大力宣传优秀事迹和先进榜样, 让优秀的同学分享成长的感悟和经验, 充分发挥榜 样引领作用。可以结合“榜样的力量”事迹展、“最美大学生”评选等活动，用“青春榜样”引领 成长, 促进大学生共同进步。还可依托创新班、精英班等, 创新人才培养模式, 先培养一批 比较优秀的同学，再发挥这些优秀同学的示范引领作用，带领广大同学共同进步。

前文提到, 充分尊重受教育者的主体性, 激发教育主体接受教育的动力, 能很好地增强 育人实效。可开展个性化的咨询辅导服务, 有针对性地结合学生们的特点, 发掘他们的潜能, 给他们进行有效的生涯规划与辅导, 还可结合先进榜样的案例, 激发他们提升核心素养的内 驱力。如面向学习动力不足的学生, 可结合逆袭北大的刘媛媛的案例来激励他们, 点然他们 学习成长的核动力, 促进他们个性化成长, 成为新时代的人才。

\section{5 善用新媒体新技术，增强教育时代感}

时下，大学生的学习与生活，具有非常强的新媒体依赖性。将新媒体新技术广泛应用于 教育教学, 是时代发展的需要。高校应善借新媒体的优势, 用活新媒体, 规避网络风险, 加 强网络思想政治教育, 引导大学生弘扬正能量。教师可以多制作高水平的微课和PPT、微视 频等, 运用现代信息技术再现情境, 激发学生的学习兴趣。课外, 高校可举办各类新媒体大 赛或“互联网+”比赛。如微视频、微电影制作比赛、“互联网+”创新创业大赛、新媒体创意展 示大赛、志愿服务项目新媒体展示大赛、优秀网络作品比赛等。在注意意识形态安全的情况 下，充分发挥新媒体的优势，增强教育的时代性和感召力。

\section{References}

[1] Zhao Rana. Why should we mention "Key Competences" (in-depth focus). People's Daily [N] 2016.10.13

[2] Cai Qingtian.Key Competences: The Target Source of the New Curriculum Reform [N]. Chinese Journal of Social Sciences, 2010-10. 